\title{
The Onconeural Antigen Nova-1 Is a Neuron-Specific RNA-Binding Protein, the Activity of which Is Inhibited by Paraneoplastic Antibodies
}

\author{
Ronald J. Buckanovich, Yolanda Y. L. Yang, and Robert B. Darnell \\ Laboratory of Molecular Neuro-Oncology, The Rockefeller University, New York, New York 10021
}

Nova-1, a protein expressed in tumors and neurons, is a target antigen in a human paraneoplastic motor disorder [paraneoplastic opsoclonus-myoclonus ataxia (POMA)]. We evaluated the relationship between the function of Nova- 1 and its role as a disease antigen. We show that Nova-1 is a neuron-specific RNA-binding protein with sequence and functional similarities to FMR-1. Nova-1 mRNA is restricted to the subcortical nervous system, and the protein binds to RNA with high affinity. Nova-1 KH domains mediate this RNA binding, and point mu- tations within them abrogate binding. POMA disease antisera $(6 / 6)$ recognize the third $\mathrm{KH}$ domain but not an inactive point mutant, and affinity-purified antibody blocks Nova-1 RNA binding. Thus, a cardinal feature of POMA is the production of antibodies that inhibit Nova-1-RNA interactions, suggesting such inhibition may cause the neurological disease.

Key words: neuron-specific gene expression; paraneoplastic neurological disease; RNA-binding protein; Nova-1 onconeural antigen; autoimmunity; opsoclonus-myoclonus ataxia
Patients with paraneoplastic neurological degenerations (PND) develop immune responses to tumor cell antigens that normally are expressed only in neurons (onconeural antigens), leading to effective anti-tumor immune responses (Anderson et al., 1988; Dalmau et al., 1990; Darnell and DeAngelis, 1993) and discrete autoimmune neurological syndromes (Posner and Furneaux, 1990; Darnell, 1994). These disorders provide unique opportunities to identify neuron-specific genes that are expressed in discrete regions of the brain. High-titer antibodies from several PND syndromes have been used to clone genes encoding onconeural antigens, leading to the identification of proteins expressed in both PND tumors and neurons from affected areas of the nervous system. For example, the Yo antibody, found in patients with cerebellar degeneration and breast or ovarian tumors (Peterson et al., 1992), was used to identify a novel neuronal leucine-zipper protein expressed in cerebellar Purkinje neurons and tumors obtained from these patients (Dropcho et al., 1987; Sakai et al., 1990; Fathallah-Shaykh et al., 1991). Recoverin, an onconeural antigen targeted in small-cell lung tumors of patients who develop paraneoplastic blindness (Polans et al., 1991; Thirkill et al., 1992), is a protein involved in CGMP-gated receptor signaling in the photoreceptor (Dizhoor et al., 1991; Gray-Keller et al., 1993; Kawamura et al., 1993). These observations, together with evidence for the active synthesis of antibodies to onconeural antigens in the CSF (Posner and Furneaux, 1990) and the detection of $T$ and $B$ cells in the brains of affected patients (Posner and Furneaux, 1990; Hormigo et al., 1994; Jean et al., 1994), have led to

Received Sept. 25, 1995; revised Nov. 6, 1995; accepted Nov. 9, 1995.

This work was supported by Grants KO8-NSO1461 and RO1 NS34389 from NINDS and Grant VM-30 from the American Cancer Socicty (R.B.D.). R.J.B. was supported by a National Institutes of I Iealth MSTP training grant (5T32-GM07739), and Y.Y.L.Y. was supported by National Research Service Award training Grant CA-09673-18. We thank J. Okano for assistance with in situ hybridization, A. Hemmati-Brivanlou for NCAM antibody, and T. DeLange and members of our laboratory for discussion and critical reading of this manuscript.

Correspondence should be addressed to Dr. Robert B. Darnell, Laboratory of Molecular Neuro-Oncology, Rockefeller University, 1230 York Avenue. New York. NY 10021.

Copyright $\bigcirc 1996$ Society for Neuroscience $0270-6474 / 96 / 161114-(09 \$ 05.00 / 0$ the hypothesis that PNDs are immunologically mediated neuronal degenerations triggered by malignancies.

Two classes of onconeural antigens share homology with two distinct families of RNA-binding proteins (RBPs). Nova-1 is an onconeural antigen recognized by the antisera of patients with paraneoplastic opsoclonus-myoclonus ataxia (POMA), a motor disorder of brainstem, cerebellar, and spinal motor neurons associated with breast cancer. POMA patients harbor high titers of an antibody reactive with a neuronal and tumor cell antigen of 55 kDa (Luque et al., 1991), which was used to clone Nova-l (Buckanovich et al., 1993). The predicted Nova-1 protein has three putative RNA-binding motifs homologous to $\mathrm{KH}$ motifs present in hnRNP-K (Buckanovich et al., 1993; Burd and Dreyfuss, 1994), an RBP without a known function (Dreyfuss et al., 1993). Similar $\mathrm{KH}$ motifs also are present in MER-1, a yeast RBP that regulates splicing of the MER-2 gene (Engebrecht et al., 1991; Nandabalan and Roeder, 1995), PSI, a Drosophila RBP that negatively regulates P-element mRNA splicing (Siebel et al., 1995), and FMR-1, the fragile-X gene implicated in mental retardation (Ashley et al., 1993; Gibson et al., 1993; Siomi et al., 1993). A second family of RBPs (HuC/PLE21, HuD, and Hel-N1) is a set of target antigens in paraneoplastic encephalomyelopathy-sensory neuropathy (Szabo et al., 1991; Levine et al., 1993; Sakai et al., 1993), a spectrum of neurological disorders associated with small-cell lung cancer (Dalmau et al., 1991). The Hu proteins contain three RNA-recognition motifs that are highly homologous with two Drosophila proteins, elav, which is essential for neurogenesis ( Yao et al., 1993), and sex-lethal, an RBP that regulates alternative splicing and, therefore, sexual differentiation (Baker, 1989; Valcarcel et al., 1993).

The association of RBPs with several distinct neurological syndromes raises the possibility that interference with the function of neuronal RBPs (n-RBPs) leads to human neurological disease. Evidence in support of this suggestion comes from the characterization of FMR-1, which was defined as an RBP by its ability to bind to ribohomopolymers in vitro (Siomi et al., 1993, 1994). A single individual with severe mental retardation was found to have 
a point mutation within one $\mathrm{KH}$ domain (DeBoulle et al., 1993), and this mutation disrupts ribohomopolymer binding in vitro (Siomi et al., 1994). To examine the role of Nova-1 as a target antigen in POMA, we have undertaken an analysis of its function in vitro, and our results suggest several parallels between Nova-1 and FMR-1. Both are associated with neurological disease, although only Nova-1 is neuron-specific in its expression and associated disease manifestations. Both bind RNA with similar sequence specificity in vitro; this activity maps to the $\mathrm{KH}$ domains of both proteins and is abrogated by analogous point mutations within them. Moreover, we have found that a hallmark of POMA is that disease antisera recognize only functional (RNA-binding) Nova-1 KH3 domains, and that affinity-purified POMA antibody blocks Nova-1 RNA binding. Taken together, these data support the hypothesis that disruption of $n$-RBP function generates some human neurological disorders.

\section{MATERIALS AND METHODS}

Protein alignments. KH-domain alignment was made using the Geneworks (IntelliGenetics, Mountain View, CA) and MACAW programs (written by $\mathrm{G}$. Schuler, National Center for Biotechnology Information).

Affinity purification of antibodies. The full-length Nova protein (NFP) was coupled covalently to cyanogen bromide Sepharose 4B (Pharmacia, Uppsala, Sweden) according to the manufacturer's instructions. POMA antiserum $(10 \mathrm{ml})$ was spun at $40,000 \times g$ to remove precipitates, and the supernatant was incubated with $2 \mathrm{ml}$ of NFP-cyanogen bromide Sepharose overnight in RIPA buffer (150 mM NaCl, $50 \mathrm{~mm}$ Tris, pH 7.4, $0.1 \%$ SDS. $0.1 \%$ Nonidet P-40, and $0.5 \%$ deoxycholate). Sepharose was washed five times in $50 \mathrm{ml}$ of RIPA, column-eluted with $4 \mathrm{ml}$ of $0.2 \mathrm{M}$ glycine, $\mathrm{pH}$ 2.5, neutralized with $1 \mathrm{M}$ Tris, $\mathrm{pH} 9.5$, and dialyzed against PBS.

Immunofluorescence and in situ hybridization. For immunohistochemistry. $12 \mu \mathrm{m}$ frozen mouse brain sections were fixed in acetone/methanol (1:1) for $2 \mathrm{~min}$, washed three times in $0.1 \%$ Triton X-100 in PBS, blocked in $10 \%$ normal goat serum and $50 \mathrm{~mm}$ glycine in PBS, washed three times, and incubated with primary antibodies overnight [dilutions used: rabbit glial fibrillary acidic protein (GFAP), 1:300; affinity-purified POMA antibodies, 1:50]. Slides were washed three times in $0.25 \%$ gelatin-PBS, incubated with secondary antibodies (FITC anti-rabbit and rhodamine anti-human, Vector, Burlingame, CA) for $45 \mathrm{~min}$ and washed three times in gelatin-PBS.

For in sill hybridization, sense and antisense RNAs from bp $2399-$ 4129 of the mouse Nova-I 3'-untranslated region (UTR) were transcribed in vitro with T7 RNA polymerase and $\left[{ }^{35}\right.$ S] uridine triphosphate to a specific activity of $2 \times 10^{9} \mathrm{cpm} / \mu \mathrm{g}$. In situ hybridization was performed with fresh-frozen $12 \mu \mathrm{m}$ sections using a method adapted from previous descriptions (Queva et al., 1992) and a hybridization temperature of $60^{\circ} \mathrm{C}$. Slides were dipped in Kodak NTB2 emulsion (Rochester, NY), exposed in the dark for 3-4 d, developed, and counterstained with cresyl violet.

Fusion proteins. A cDNA encoding NFP, PCR-generated fragments haboring the Nova-1 KH1 domain (N1) or KH3 domain (N3), and a gene encoding a control protein (Yo) (Fathallah-Shaykh et al., 1991) were cloned into pET21B (Novagen, Madison, WI) such that each was in an open reading frame encoding the T7 epitope at the $\mathrm{N}$ terminus with a histidine tag at the $\mathrm{C}$ terminus. All clones were sequenced in their entirety to ensure fidelity of the PCR reaction. The $N 3^{1.21 N}$ protein was constructed by site-directed oligo-based mutagenesis. The N1 ${ }^{1 / 4^{\prime} \mathrm{I}}$ fusion protein was isolated from a PCR AUU $\rightarrow$ ACU mutation. Fusion proteins were purified by nickel-chelation chromatography.

Ribohomopolymer and single-stranded DNA agarose-binding assays. NFP (500 ng) or equimolar amounts of $\mathrm{N} 1$ and $\mathrm{N} 3$ fusion proteins were incubated with ribohomopolymer agarose or single-stranded DNA (ssDNA) agarose (Sigma, St. Louis, MO) in $1 \mathrm{ml}$ of RSB-binding buffer (Swanson and Dreyfuss, 1988) containing the indicated $\mathrm{NaCl}$ concentraliuns and $1 \mathrm{mg} / \mathrm{ml}$ leparin (Sigma). Agarose was washed five times in binding buffer, and bound protein was analyzed by SDS-PAGE and Western blot using a T7 monoclonal antibody (Novagen) and enhanced chemiluminescence (Amersham, Arlington Heights, IL). To control for protein loading, an amount equivalent to $20 \%$ of the fusion protein used in each binding assay was loaded $(+)$. Binding for quantitative analysis was performed in $1 \mathrm{ml}$ of $250 \mathrm{~mm} \mathrm{NaCl-RSB}$, heparin, and the indicated amounts of protein. Western blots were quantitated by densitometry.
Northwestem analysis. Equimolar amounts of indicated fusion proteins were run on SDS-PAGE and transferred to nitrocellulose. Protein blots were blocked overnight in binding buffer $(10 \mathrm{mM}$ Tris, $\mathrm{pH} 7.4,50 \mathrm{~mm}$ $\mathrm{NaCl}, 1 \mathrm{~mm}$ F.DTA, $2 \times$ Denhardt's solution, and $100 \mu \mathrm{g} / \mathrm{ml}$ tRNA), probed with a ${ }^{32} \mathrm{P}$ end-labeled polyriboguanosine probe, washed four times for $15 \mathrm{~min}$ in binding buffer, and exposed to film. Filter was washed twice for $30 \mathrm{~min}$ at $55^{\circ} \mathrm{C}$ in stripping buffer $(100 \mathrm{~mm} \beta$-mercaptoethanol, $2 \%$ SDS, $62.5 \mathrm{~mm}$ Tris- $\mathrm{HCl}$ ) and then reprobed with $\mathrm{T} 7$ antibody.

Binding to brain $R N A$. NFP or control fusion protein (50 $\mu \mathrm{g}$ ) was incubated with $10 \mu \mathrm{g}$ of total mouse brain RNA prepared as described previously (Chomcynski and Sacchi, 1987) in RNA-binding buffer (Levine et al., 1993). Proteins then were immunoprecipitated in the same buffer with the indicated antibodies and washed five times with binding buffer, and then bound RNA was phenol-extracted, DNase digested, and ethanol precipitated. RNA was reverse-transcribed and PCR-amplified in the presence of $\left[\alpha^{-32} \mathrm{P}\right]$ deoxycytidine triphosphate as described previously (Buckanovich et al., 1993), using Nova-1-, actin-, or neuronal Adaptinlike protein (NAP)-specific primers. To ensure RNA integrity, total brain RNA also was amplified ( + control). As a control for DNA contamination, each RNA sample was analyzed in duplicate with or without $(+$ or - ) reverse transcriptase (Buckanovich et al., 1993). Ten percent of each PCR product was analyzed by nondenaturing PAGE, and the gel was dried and exposed to film.

$R N A$-protein filter-binding assay. Fusion protein ( $100 \mathrm{ng})$ was incubated in the indicated concentrations of affinity-purified antibody and bovine serum albumin for $30 \mathrm{~min}$ at room temperature in $100 \mu \mathrm{l}$ of binding buffer (250 $\mathrm{mm} \mathrm{LiCl}, 20 \mathrm{~mm}$ Tris, $\mathrm{pH} \mathrm{7.4,} \mathrm{and} 10 \mathrm{mM} \mathrm{MgCl}_{2}$ ). ${ }^{32} \mathrm{P}$ end-labeled riboguanosine $(\mathrm{rG} ; 100 \mathrm{ng}$ ) was added and incubated for $25 \mathrm{~min}$ at room temperature. Samples were vacuum-filtered through $0.2 \mu \mathrm{M}$ nitrocellulose, washed with 1 volume of cold binding buffer, and analyzed in a scintillation counter.

\section{RESULTS}

\section{Nova-1 expression is restricted to a subset of neurons}

Nova antigens have been reported previously to be restricted to the CNS (Buckanovich et al., 1993; Graus et al., 1993). To determine whether Nova protein is restricted to neurons, we labeled adult mouse brain sections with anti-GFAP and affinity-purified POMA antibodies. Double-label immunofluorescence analysis revealed that GFAP and Nova antigen expression is mutually exclusive throughout the CNS (Fig. 1 $A$ ) (data not shown). Nova antigen expression is confined primarily to neuronal nuclei which, together with data presented below, suggests that Nova functions as a nuclear RBP. To confirm that the cells recognized by POMA antibodies were neurons, we performed double-labeling experiments with affinity-purified POMA antibodies and either antineural cell adhesion molecule (NCAM) or anti-neuron-specific enolase (NSE) antibodies. Nova antigen is expressed in all cells recognized by NCAM (Fig. 1B,C) and NSE (data not shown). These results, together with the demonstration that Nova protein expression is absent from white matter tracts (Buckanovich et al., 1993), demonstrate that expression of the Nova antigen is neuron-specific.

The specificity of neurological dysfunction (oculomotor-brainstem-cerebellum) in POMA (Posner and Furneaux, 1990; Darnell, 1994) contrasts with reports that the Nova antigen is expressed in all CNS neurons (Luque et al., 1991; Graus et al., 1993). This may be explained in part by the identification of a second, closely related Nova gene (Nova-2) (Buckanovich et al., 1993) (R. B. Darnell, Y. Y. L. Yang, and G. L. Yin, unpublished data). Thus, we examined Nova-1 expression in mouse brain by in situ hybridization with Nova-l gene-specific probes. These data revealed striking regional localization of Nova-l mRNA expression in ventral diencephalon, midbrain, cercbellum, and hindbrain. Expression was strongest in the midbrain and pontine tegmentum, optic tectum (Fig. $1 D, E$ ), and deep cerebellar nuclei (data not shown). There was a distinct absence of reactivity in 
Figure 1. Nova-1 is neuron-specific and restricted to the subcortical CNS. $A$, Immunofluorescence double exposure of GFAP (green) and Nova (red) in a section of adult mouse hindbrain demonstrating that GFAP and Nova reactivities are nonoverlapping. GFAP reactivity is detected in the cytoplasm and processes of glial cells, whereas Nova reactivity is detected strongly in neuronal nuclei and more weakly in the neuronal cytoplasm. Scale bar, $10 \mu \mathrm{m}$. $B, C$, Immunofluorescence exposure of NCAM (green) and Nova (red) in a section of adult mouse neocortex demonstrating that NCAM and Nova reactivities are overlapping. NCAM reactivity is detected in the neuronal cytoplasm, whereas Nova reactivity is detected primarily in neuronal nuclei and more weakly in the neuronal cytoplasm. Scale bar, 10 $\mu \mathrm{m}$. $D$, Dark-field microscopy of Nova-1 in situ hybridization in a P8 mouse brain sagittal section. A gene-specific antisense riboprobe corresponding to the $3^{\prime}$-UTR Nova-1 cDNA sequence was used for hybridization; similar results were observed using a coding-region probe at high stringency (data not shown). Reactivity (white) is observed in the rhinencephalon $(R)$, hypothalamus and preoptic area $(H)$, pons $(P)$, midbrain $(M b)$, cerebellum $(C b)$, and medulla $(M)$. No reactivity was detected in the neocortex $(N)$ or thalamus $(T)$, and no reactivity was observed with a sense riboprobe (data not shown). $E$, High-power exposure of a coronal section at the level of the cerebellum and medulla. Nova-1 reactivity is observed in all neurons of the medulla as well as in the Purkinje and granule cells of the cerebellum. There is no reactivity in white matter tracts [e.g., in the pyramidal tract $(P y)]$.
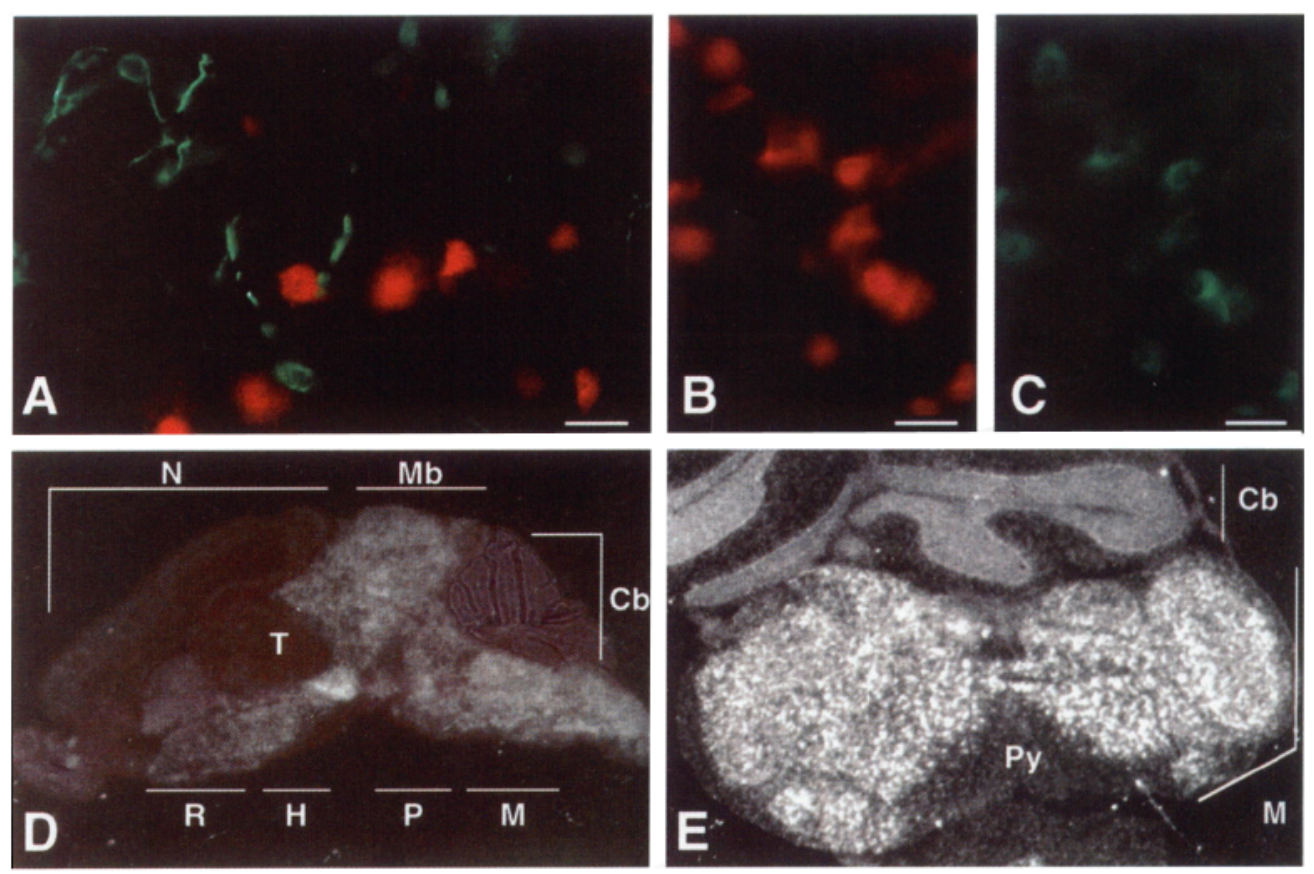

neocortex, thalamus, and white matter tracts (Fig. $1 D, E$ ). Thus, the expression of the Nova-1 gene is restricted to neurons within discrete regions of the mammalian $\mathrm{CNS}$, in a pattern that correlates with the presence of brainstem and cerebellar symptoms and the absence of sensory or neocortical symptoms observed in POMA patients.

\section{Nova-1 is an RBP}

Nova-1 encodes three potential RNA-binding domains (RBDs) homologous to the KH domains of hnRNP-K, FMR-1, the Drosophila alternative splicing factor PSI and Bicaudal-C proteins, the yeast alternative splicing factor MER-1, and others (Burd and Dreyfuss, 1994) (Fig. 2). This domain appears to be a functional protein motif in vivo: a severely affected fragile- $\mathrm{X}$ syndrome patient harbors a point mutation (I367N substitution) within the core of the conserved KH element (DeBoulle et al., 1993) (see Fig. 2). Similarly, mutations of the core of the third KH domain of Bicaudal-C leads to loss of function in vivo (Mahone et al., 1995), and mutations in the KH domains of hnRNP-K and FMR-1 decrease RNA-binding activity in vitro (Siomi et al., 1994).

Putative RBPs have been functionally characterized and classified based on their ability to bind ribohomopolymers in vitro (Swanson and Dreyfuss, 1988; Dreyfuss et al., 1993; Burd and Dreyfuss, 1994). To determine whether Nova-1 binds to RNA in vitro, we analyzed the ability of a T7 epitope-tagged NFP to bind ribohomopolymers. Binding was detected by Western blot analysis

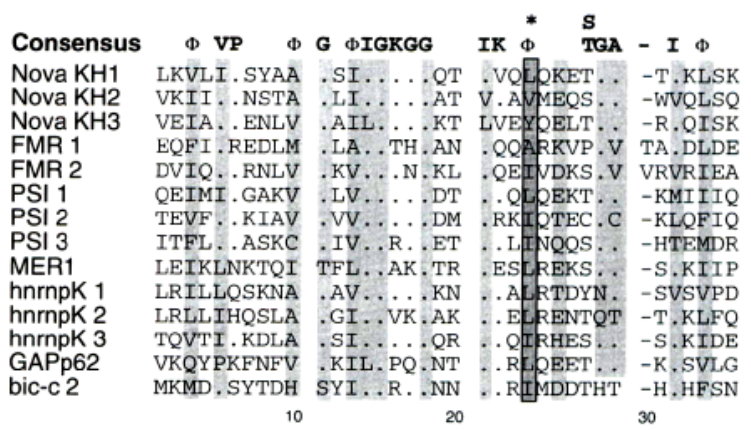

Figure 2. Alignment of the 36-amino-acid Nova-1 KH domains with related proteins. A statistically significant consensus sequence is shown at the top that encompasses the central 28 amino acids of the $\mathrm{KH}$ domain; within individual KH domains, amino acids identical to the consensus are indicated as dots, and amino acid homologies are shaded. A single amino acid (amino acid 21, ${ }^{*}$ ) is a highly conserved hydrophobic amino acid in which an in vivo mutation (I367N) in the second FMR-1 KH domain leads to severe mental retardation. In addition, in vitro mutation of this amino acid leads to diminished RNA binding of FMR-1, hnRNP-K (Siomi et al., 1994), and Nova-1 (Fig. 3). Next to each gene the number of the $\mathrm{KH}$ domain shown is indicated; $\Phi$ indicates a hydrophobic amino acid. Protein sequences were obtained from the following references: Nova-1 (KH1-3) (Buckanovich et al., 1993); FMR KH domains 1-2 (Siomi et al., 1993); PSI KH domains 1-3 (Siebel et al., 1995); MER1 (Engebrecht and Roeder, 1990); hnRNP-K KH domains 1-3 (Matunis et al., 1992); GAPp62 (Wong et al., 1992); Bicaudal-C KH domain 2 (bic-c) (Mahone et al., 1995). Additional KH homologies are reviewed elsewhere (Burd and Dreyfuss, 1994). 


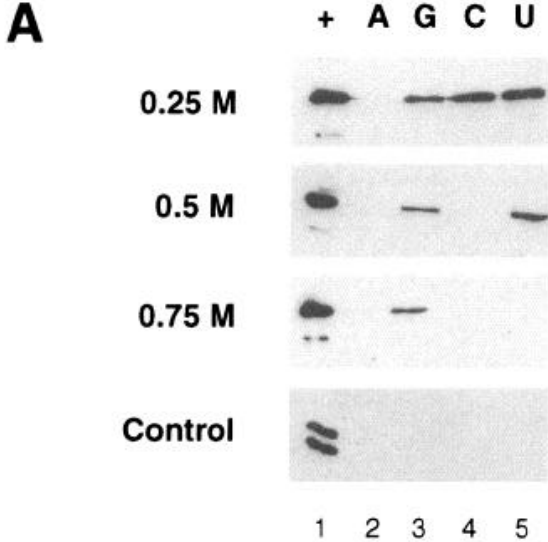

B

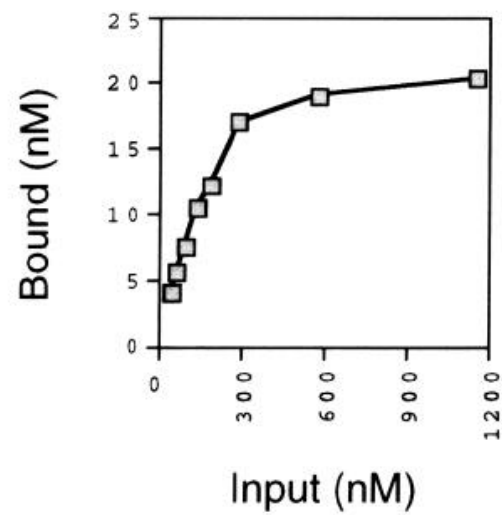

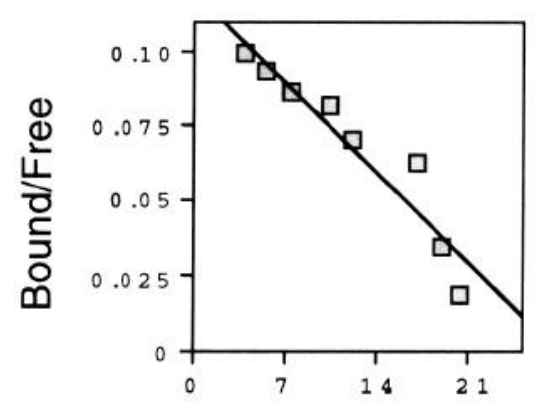

Bound (nM)
Figure 3. Nova-1 binds RNA in vitro. A, T7-tagged Nova-1 NFP was bound to the indicated ribonucleotide homopolymers at varying salt concentrations; after washing, bound protein was detected by Western blot analysis using a T7 monoclonal antibody $(\mathrm{A}, \mathrm{G}, \mathrm{C}$, and $U$ binding assays are shown in lanes $2,3,4$, and 5 , respectively). NFP bound to $\mathrm{G}, \mathrm{C}$, and $\mathrm{U}$ ribohomopolymers in $0.25 \mathrm{M} \mathrm{NaCl}$, to $\mathrm{rG}$ and $\mathrm{rU}$ in $0.5 \mathrm{M}$ $\mathrm{NaCl}$, and only to $\mathrm{rG}$ in $0.75 \mathrm{M} \mathrm{NaCl}$. NFP bound to all four ribohomopolymers in $0.1 \mathrm{M} \mathrm{NaCl}$ (data not shown). An irrelevant T7-tagged protein (Control) showed no detectable binding to A, G, C, or U ribohomopolymers in $0.25 \mathrm{M} \mathrm{NaCl}$. To control for the amount of protein present in each assay, $20 \%$ of the protein from each reaction was reserved before ribohomopolymer binding and loaded directly in lane 1 (+). B, Binding plot of NFP to $\mathrm{rG}$. The amount of NFP added to each reaction is indicated on the $x$-axis, and the amount of NFP bound to RNA is indicated on the $y$-axis. $C$, Scatchard analysis of NFP binding to $\mathrm{rG}$. The $x$-axis shows the concentration of NFP protein bound to $\mathrm{rG}$, and the $y$-axis gives the ratio of protein bound to $\mathrm{rG}$ compared with unbound protein. Slope of the line $\left(-1 / K_{\mathrm{d}}\right)$ yields a $K_{\mathrm{d}}$ of $\sim 250 \mathrm{~nm}$. using a monoclonal antibody directed against the T7 epitope. At low stringency $(0.25 \mathrm{M} \mathrm{NaCl})$, NFP bound all ribohomopolymers except $\mathrm{rA}$, whereas control proteins showed no detectable binding. At intermediate stringency $(0.5 \mathrm{M} \mathrm{NaCl})$ NFP bound preferentially to $\mathrm{rG}$ and $\mathrm{rU}$, and at high stringency $(0.75 \mathrm{M} \mathrm{NaCl}) \mathrm{NFP}$ bound only to rG (Fig. $3 A$ ). Thus, Nova-1 binds RNA in vitro and binds with the same ribonucleotide preference as FMR-1 ( $\mathrm{rG}>$ $\mathrm{rU} \gg \mathrm{rA}$ and $\mathrm{rC}$ ), in contrast to the binding preference ( $\mathrm{rC}$ ) of hnRNP-K and several other KH-type RBPs.

To quantitate NFP binding to rG, we mixed increasing concentrations of protein with constant concentrations of RNA, separated bound from unbound protein, and quantitated the results using Western blot analysis. Binding plots revealed that NFP bound to $\mathrm{rG}$ with high affinity in a saturable manner. Using Scatchard analysis, we estimate that NFP bound to $\mathrm{rG}$ with a dissociation constant $\left(K_{\mathrm{d}}\right)$ of $250 \mathrm{~nm}$ in $0.25 \mathrm{M} \mathrm{NaCl}$ (Fig. $3 B, C$ ). The affinity of Nova-1 for $\mathrm{rG}$ is similar to that observed for other RBPs bound to ribohomopolymers (e.g., $\sim 200 \mathrm{~nm}$ for the polypyrimidine tract-binding protein) (McCarthy and Kollmus, 1995).

To define the domain of Nova-1 that binds to RNA in vitro, we constructed several truncated Nova-1 fusion proteins. One protein (N1) encompasses the $\mathrm{N}$ terminus and first $\mathrm{KH}$ motif of Nova-1; a second $\left(\mathrm{N} 1^{\mathrm{I1}}{ }^{\mathrm{T}}\right)$ is identical to $\mathrm{N} 1$ but harbors an isoleucine $\rightarrow$ threonine mutation at position 14 of the first $\mathrm{KH}$ motif; a third (N3) encompasses the third $\mathrm{KH}$ domain and $\mathrm{C}$ terminus of Nova-1; and a fourth $\left(\mathrm{N} 3^{\mathrm{L} 21 \mathrm{~N}}\right)$ is identical to the $\mathrm{N} 3$ construct but harbors a leucine $\rightarrow$ asparagine mutation in position 21 of the third $\mathrm{KH}$ motif (Fig. 2). The $\mathrm{N} 3^{\mathrm{L} 21 \mathrm{~N}}$ mutation is precisely analogous to the FMR-1 $\mathrm{I} 367 \mathrm{~N}$ in vivo $\mathrm{KH}$ domain mutation (see Fig. 2). Ribohomopolymer-binding assays demonstrated that both $\mathrm{N} 1$ and $\mathrm{N} 3$ maintained the same sequence preference $(\mathrm{rG}>\mathrm{rU})$ as the NFP, whereas $\mathrm{N} 1^{114 \mathrm{~T}}$ and $\mathrm{N} 3^{\mathrm{L} 21 \mathrm{~N}}$ showed markedly reduced RNA binding to rG (Fig. 4A) (data not shown). Quantitation of $\mathrm{N} 3$ and $\mathrm{N} 3^{\mathrm{L} 2 \mathrm{NN}}$ binding to $\mathrm{rG}$ demonstrated that $\mathrm{N} 3$ has a $>25$-fold affinity for rG than N3 ${ }^{\mathrm{L} 21 \mathrm{~N}}\left(\mathrm{~N} 3, K_{\mathrm{d}}\right.$ $\sim 750 \mathrm{~nm} ; \mathrm{N} 3^{\mathrm{L} 21 \mathrm{~N}}, K_{\mathrm{d}} \sim 20 \mu \mathrm{M}$; Fig. $\left.4 B, C\right)$.

As an independent measure of Nova-1 RNA binding, Northwestern assays were performed. NFP, N3, N $3^{\mathrm{L} 21 \mathrm{~N}}$, and a control fusion protein were immobilized on nitrocellulose and probed with a poly-rG riboprobe. NFP and N3 bound to the rG riboprobe, whereas $\mathrm{N} 3^{\mathrm{L} 21 \mathrm{~N}}$ and the control fusion protein did not (Fig. 5). The blot was stripped and reprobed with T7 antibody, revealing fusion protein present in each lane (Fig. 5). These experiments demonstrate that the Nova-1 KH domain is sufficient for sequence-specific binding to RNA in vitro, and that disruption of this domain markedly interferes with that binding.

To determine whether Nova-1 is capable of binding to in vivo brain RNAs, we incubated NFP with total mouse brain RNA. After immunoprecipitating NFP, RNA binding was detected by amplifying specific RNAs using reverse-transcription PCR. Using this analysis, NFP selectively bound some (Nova-1 and actin), but not all ( $\beta$-NAP), abundant neuronal RNAs examined (Fig. 6). No 
A

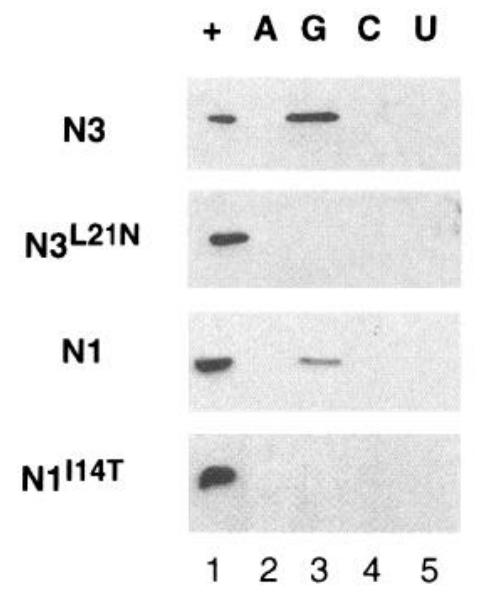

Figure 4. RNA binding and mutational analysis of the $\mathrm{N} 1$ and $\mathrm{N} 3$ Nova-1 KH domains. $A$, The first $(N 1)$ and third $(N 3) \mathrm{KH}$ domains of Nova-1 bind preferentially to $\mathrm{rG}$ ribohomopolymers in $0.25 \mathrm{M} \mathrm{NaCl}(A, G, C$, and $U$ in lanes 2, 3, 4, and 5, respectively). $N 1^{I l 4 T}$ and $N 3^{L 21 N}$ show no detectable RNA binding. Twenty percent of the amount of protein used in each binding assay was loaded in lane $1(+)$. The N1 construct encodes amino acids $1-87$, and the N3 construct encodes amino acids 427-511 of Nova-1 (Buckanovich et al., 1993). B, Binding plot of $\mathrm{N} 3$ and $\mathrm{N} 3^{\mathrm{L} 2 \mathrm{~N}}$ to $\mathrm{rG}$. The input protein is indicated on the $x$-axis, and the amount of protein bound to RNA is indicated on the $y$-axis. $C$, Scatchard plot analysis of $\mathrm{N} 3$ and $\mathrm{N} 3^{\mathrm{L} 2 \mathrm{~N}} \mathrm{rG}$ binding. The $x$-axis shows the concentration of protein bound to RNA, and the $y$-axis shows the ratio of protein bound to RNA and unbound protein. Slope of the line $\left(-1 / K_{\mathrm{d}}\right)$ yields a $K_{\mathrm{d}}$ of $\sim 750$ $\mathrm{nM}$ and $20 \mu \mathrm{M}$ for $\mathrm{N} 3$ and $\mathrm{N} 3^{\mathrm{L} 21 \mathrm{~N}}$, respectively.

\section{B}

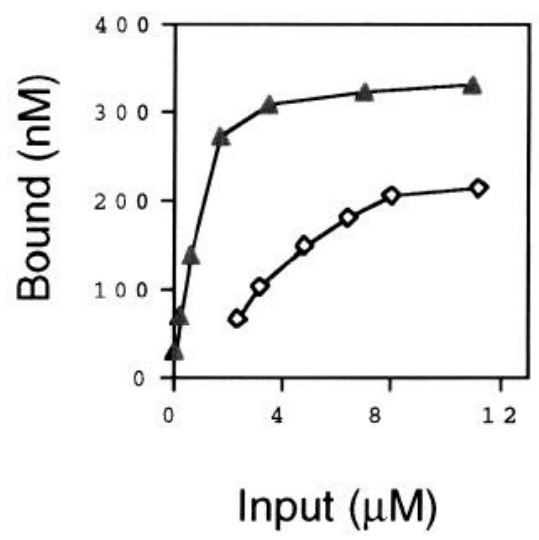

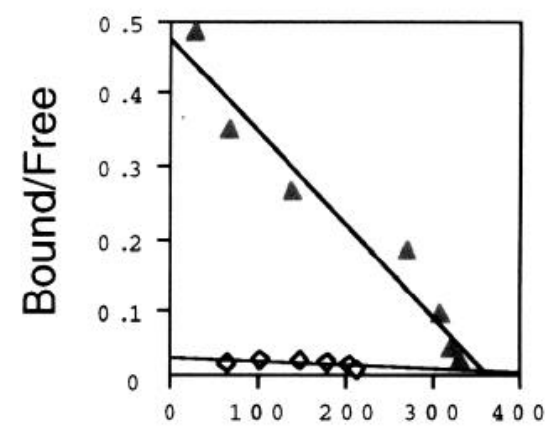

Bound (nM) bound RNA was detectable after immunoprecipitation of an irrelevant protein or after mock immunoprecipitation of NFP with normal human serum. These results demonstrate that Nova-1 is able to bind in vivo brain RNAs.

Because several RBPs bind to ssDNA as well as ribohomopolymers in vitro (Dreyfuss et al., 1993), we examined whether Nova-1 was able to bind to ssDNA. Although control proteins showed no detectable binding, NFP stably interacted with ssDNA even under stringent conditions $(4 \mathrm{M} \mathrm{NaCl}$; Fig. $7 A$ ). Similarly strong interactions have been observed between ssDNA and hnRNP-K or FMR-1 (Dreyfuss et al., 1993). Unlike NFP, neither N1 nor N3 isolated $\mathrm{KH}$ domain protein-bound ssDNA (Fig. 7B). These results suggest that the Nova-1 KH domains function preferentially as RBDs.

\section{Autoimmune antisera bind the functional Nova-1 RNA-binding motif}

It has been suggested that autoimmune epitopes map to functional domains of target proteins (Tan, 1991). Because we have defined the Nova-1 KH domain as a functional RBD in vitro and previously have mapped the target epitope of POMA autoimmune sera to the third KH domain of Nova-1 (Buckanovich et al., 1993), we examined whether there was a relationship between the function of Nova-1 and the binding of POMA antisera to the protein. Western blot analysis of the N1 and N3 proteins confirmed that N3 encoded the autoimmune epitope (data not shown). When increasing amounts of $\mathrm{N} 3$ or $\mathrm{N} 3^{\mathrm{L} 21 \mathrm{~N}}$ protein were blotted with autoimmune POMA antiserum, we found that N3 was recognized markedly better than the $\mathrm{N} 3^{\mathrm{L} 21 \mathrm{~N}}$ point mutant (Fig. 8A). To confirm that equal amounts of $\mathrm{N} 3$ and $\mathrm{N} 3^{\mathrm{L} 21 \mathrm{~N}}$ protein were present in the assay, the blot was stripped and reprobed with a T7 monoclonal antibody (Fig. $8 A$ ). To extend this result, made with a single POMA antiserum, we repeated this analysis with five additional POMA antisera. In each case, reactivity was robust with $\mathrm{N} 3$ fusion protein but was nearly undetectable with the $\mathrm{N} 3^{\mathrm{L} 21 \mathrm{~N}}$ protein (Fig. $8 B$ ). These results indicate that the same amino acid that is essential for the RNA-binding activity of N3 is also essential for recognition of the protein by autoimmune antibodies.

The dependence of both RNA binding and antibody recognition on the same amino acid suggests that the autoimmune POMA antibody may inhibit the function of the Nova- 1 protein. To test this hypothesis in vitro, we assessed the ability of Nova-1 protein to bind soluble ribohomopolymers in the presence of antibody using a filterbinding assay. Binding of N3 to rG was inhibited by affinity-purified 

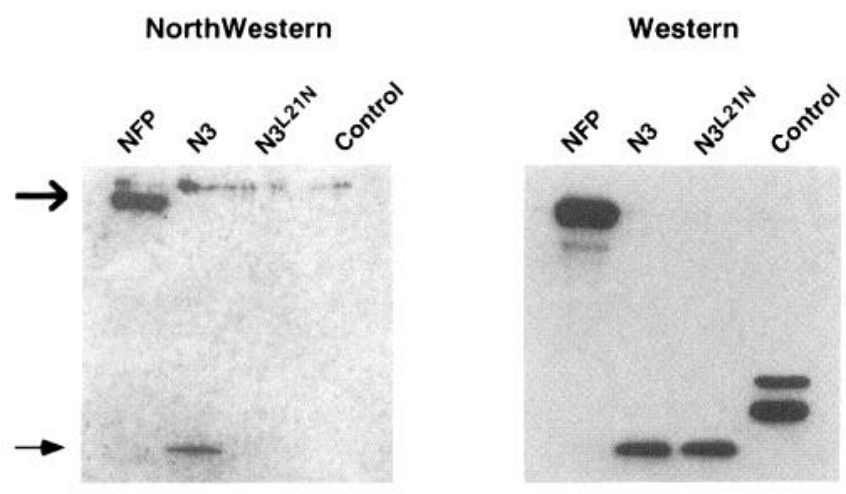

Figure 5. Northwestern blot analysis of Nova-1 RNA binding. NFP (large arrow) and $N 3$ (small arrow), $N 3^{L 2 I N}$, or a Control protein were transferred to nitrocellulose and bound to a poly-rG riboprobe (NorthWestern). RNA bound only to NFP (large arrow) and N3 (small arrow). Some nonspecific binding to bacterial proteins is present in the wells of all lanes. To confirm that approximately equal amounts of fusion protein were loaded in each lane, the blot was stripped and reprobed with a T7 monoclonal antibody (Western).

POMA antibodies in a dose-dependent manner (Fig. 8C). However, $\mathrm{N} 3$ binding was unaffected by $\mathrm{T} 7$ monoclonal or irrelevant autoimmune antibodies. In contrast, N1, which is not recognized by POMA antibodies, bound $\mathrm{rG}$ equally well in the presence of POMA or control antibodies. Surprisingly, POMA antibody inhibited NFP (which contains both $\mathrm{N} 1$ and $\mathrm{N} 3$ sequences) RNA binding as effectively as it inhibited N3 (Fig. 6C). Taken together, these results indicate that the binding of POMA antibody to N3 effectively prevents the NFP from binding to RNA.

\section{DISCUSSION}

We have determined that the Nova-1 paraneoplastic disease antigen is an n-RBP. The expression pattern of Nova- 1 mRNA and the Nova antigen appear to be restricted entirely to neurons of the CNS in the adult (Fig. 1) and developing (Buckanovich et al.,

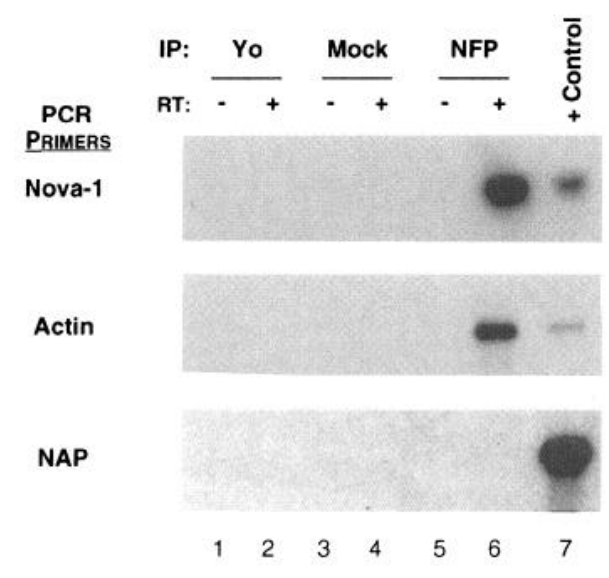

Figure 6. Nova binds in vivo RNA. NFP or a T7-tagged control fusion protein ( $\mathrm{Yo}$ ) were incubated with total mouse brain RNA. NFP was immunoprecipitated with either POMA sera (NFP; lanes 5 and 6) or normal human sera (Mock; lanes 3 and 4 ); control protein was immunoprecipitated with a T7-tagged monoclonal antibody (Yo; lanes 1 and 2 ). Bound RNAs were extracted, reverse-transcribed, and PCR-amplified using gene-specific primers to Nova-1, actin, or $\beta$-NAP (an abundant neuron-specific mRNA; see Newman et al., 1995). To ensure RNA integrity, total brain RNA also was amplified by reverse transcriptase (RT)PCR (+Control, lane 7). As a control for DNA contamination, each RNA sample was analyzed in duplicate with $(+)$ or without $(-)$ RT. NFP bound to Nova- 1 and actin, but not to $\beta$-NAP RNA.
1993) (R. Buckanovich and R. Darnell, unpublished data) mouse. Similarly restricted neuronal localization for RBPs has been described for only two other gene families. The first family contains three RNP-motif RBDs (Dreyfuss et al., 1993) and is comprised of the Drosophila genes elav and rbp9 (Campos et al., 1985; Kim and Baker, 1993; Yao et al., 1993) and their mammalian homologs, the $\mathrm{Hu}$ (Szabo et al., 1991) and Hel-N1 (Levine et al., 1993; King et al., 1994) genes in mouse, and the elr genes in Xenopus laevis (Good, 1995). A second family of n-RBPs, containing two RBDs, includes the Xenopus laevis nrp-1 (Richter et al., 1990) and Drosophila musashi (Nakamura et al., 1994) genes, which are homologous to the hnRNP A/B proteins (Dreyfuss et al., 1993; Nakamura et al., 1994). The members of these two n-RBP families have been characterized as being specifically but ubiquitously expressed in neurons of the central and peripheral nervous systems, suggesting involvement in neuronal, but not regional, specification and function within the brain. Other RBPs, including FMR-1 (Abitbol et al., 1993; Devys et al., 1993; Hanzlik et al., 1993; Hinds et al., 1993) and cpo (Bellen et al., 1992), may show some regional variation of expression within the nervous system, but also are expressed in cell types other than neurons. Nova- 1 is unique in being the first n-RBP with a tightly defined region-specific pattern of expression within the mammalian CNS. The restricted subcortical expression of Nova-1 is not only compatible with the restricted nature of POMA but also suggests that $\mathrm{n}$-RBPs perform specific roles in the development or function of discrete groups of neurons.

RBPs play important roles in post-transcriptional regulation of RNA metabolism, ranging from splicing and editing to transport,

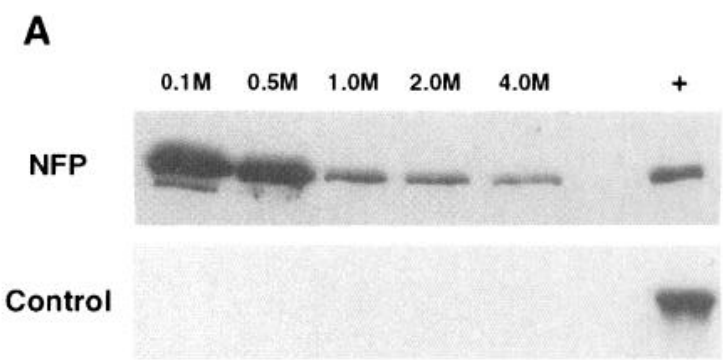

B
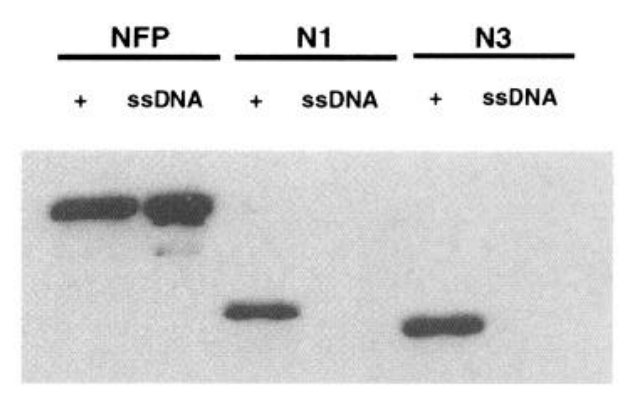

Figure 7. NFP, but not $\mathrm{N} 1$ or N3, binds ssDNA. $A$, NFP was bound to ssDNA in the presence of increasing salt $(0.1-4.0 \mathrm{M} \mathrm{NaCl})$; bound protein was assayed as described in Figure 3. Twenty percent of the amount of protein used in each binding assay was loaded as a control $(+) . B$, The binding of equimolar amounts of $N F P, N 1$, and $N 3$ to $s s D N A$ was compared under relatively nonstringent conditions $(0.25 \mathrm{M} \mathrm{NaCl})$. Under these conditions NFP bound ssDNA, whereas N1 and N3 did not. Twenty percent of the amount of protein used in each binding assay was loaded as a control (+). 
localization, and degradation (Pinol-Roma and Dreyfuss, 1992; Dreyfuss et al., 1993; Burd and Dreyfuss, 1994; McCarthy and Kollmus, 1995). Recently, two KH-type RBPs have been functionally defined to be involved in regulating alternative splicing. The yeast MER-1 protein, which has one $\mathrm{KH}$ domain, has been demonstrated to be essential for the meiosis-specific splicing of the MER-2 transcript (Engebrecht et al., 1991; Nandabalan and Roeder, 1995), although a specific RNA sequence with which the protein interacts has not been defined. The Drosophila PSI protein, which was cloned recently and was reported to have three $\mathrm{KH}$ domains, inhibits functional splicing of the P-element transposase in somatic tissues (Siebel et al., 1995). Based on the homology of Nova-1 to these proteins, it is possible that Nova- 1 is involved in regulating neuron-specific alternative splicing. However, other roles also have been attributed to KH-type RBPs; the Bicaudal-C protein, for example, which harbors five $\mathrm{KH}$ domains, has been indirectly implicated in RNA targeting (Mahone et al., 1995). Clarifying the role of Nova-1 in neurons awaits clearer identification of the RNA ligands to which it binds.

The demonstration that Nova-1 and isolated Nova-1 KH proteins bind RNA, and that point mutations within these proteins disrupt RNA binding, defines the $\mathrm{KH}$ motif as a functional domain of Nova-1. The observation that POMA antibody recognizes the third KH domain of Nova-1, but not an inactive point mutant, is consistent with the general observation that autoantibodies are unusual in recognizing functionally important domains (Tan, 1991). The Nova-1 KH motifs share sequence similarity and in vitro RNA-binding specificity with FMR-1, and mutations that abrogate RNA binding of Nova-1 and FMR-1 localize to the same amino acid within the $\mathrm{KH}$ domains. These observations suggest that Nova-1 and FMR-1 interact with similar RNA ligands in neurons. Moreover, interference with specific RNA binding may be important in the pathogenesis of the neurological syndromes associated with both FMR-1 (Ashley et al., 1993; Siomi et al., 1994) and POMA. A single severely affected patient harbors a point mutation within the second FMR-1 KH domain (DeBoulle et al., 1993), and this mutation reduces the interaction of FMR-1 with RNA in vitro (Siomi et al., 1994). Because affinity-purified POMA antibodies inhibit the in vitro RNA-binding activity of Nova-1 (Fig. 8), we propose that interference with the RNAbinding activity of Nova-1 may lead to neurological disease, similar to the proposed pathogenesis of FMR-1, but via an immunemediated rather than a genetic mechanism.

A compelling role for the isolated Nova-1 $\mathrm{KH}$ motifs as functional RBDs reflects earlier studies of the hnRNP-K and FMR-1 proteins, but differs in several respects. Although $\mathrm{KH}$ domains are necessary for RNA binding in the intact hnRNP-K and FMR-1 proteins (Siomi et al., 1993, 1994), our data provide the first evidence that they are sufficient for direct interaction with RNA in vitro (Dreyfuss et al., 1993; Burd and Dreyfuss, 1994; Siomi et al., 1994). Quantitative analysis of the RNA binding of full-length versus isolated $\mathrm{N} 1$ and $\mathrm{N} 3 \mathrm{KH}$ domains of Nova-1 reveals that they are competent to bind RNA with nearly equal affinity $\left(K_{\mathrm{d}} \sim\right.$ $250-750 \mathrm{~nm}$ in $0.25 \mathrm{M} \mathrm{NaCl}$; Figs. 3, 4) (data not shown). These results provide a plausible mechanism for interaction of RNA with proteins (such as MER-1) that contain single $\mathrm{KH}$ domains.

POMA antibody, which binds only to the third $\mathrm{KH}$ domain (Buckanovich et al., 1993) (R. Buckanovich and R. Darnell, unpublished data), abolishes the Nova-1-RNA interaction, even in the presence of two upstream RBDs (Fig. 8). This may be explained if the Nova-1 KH domains are in close physical proximity, such that the presence of antibody bound to the third Nova-1 KH domain is able to inhibit the interaction between RNA and the first and second Nova-1 KH domains sterically.
Figure 8. POMA antisera recognize wild-type $\mathrm{N} 3$, but not the $\mathrm{N} 3^{\mathrm{L} 2 \mathrm{IN}}$ point mutant, and inhibit RNA binding in vitro. A, Western blot analysis of 12.5 , 25,50 , and $100 \mathrm{ng}$ of $\mathrm{N} 3$ (lanes $1-4$ ) and $N 3^{L 2 I N}$ (lanes 5-8) using a POMAdisease antiserum (POMA-1) or T7 monoclonal antibody $(T 7) . B$, Western blot analysis with $\mathrm{T} 7$ monoclonal antibody and five additional POMA-disease antisera (POMA 2-6) with $50 \mathrm{ng}$ of $\mathrm{N3}$ and $N 3^{L 2 I N}$ proteins, $C$, RNA binding of NFP, and N3 proteins preincubated with affinity-purified $P O M A$ or irrelevant autoimmune (Control) antibodies. Neither NFP nor N3 RNA binding is affected by control antibodies; however, both are inhibited in a dose-dependent manner by POMA antibodies. POMA antibodies do not recognize $\mathrm{N} 1$ and have no affect on N1 RNA binding. Dilution of antibody used is indicated on the $x$-axis; percent RNA binding is indicated on the $y$-axis [binding with no antibody present $(\sim 20,000 \mathrm{cpm})$ was defined as $100 \%$, and background counts when no protein was present $(\sim 1250 \mathrm{cpm})$ was defined as $0 \%$ ].

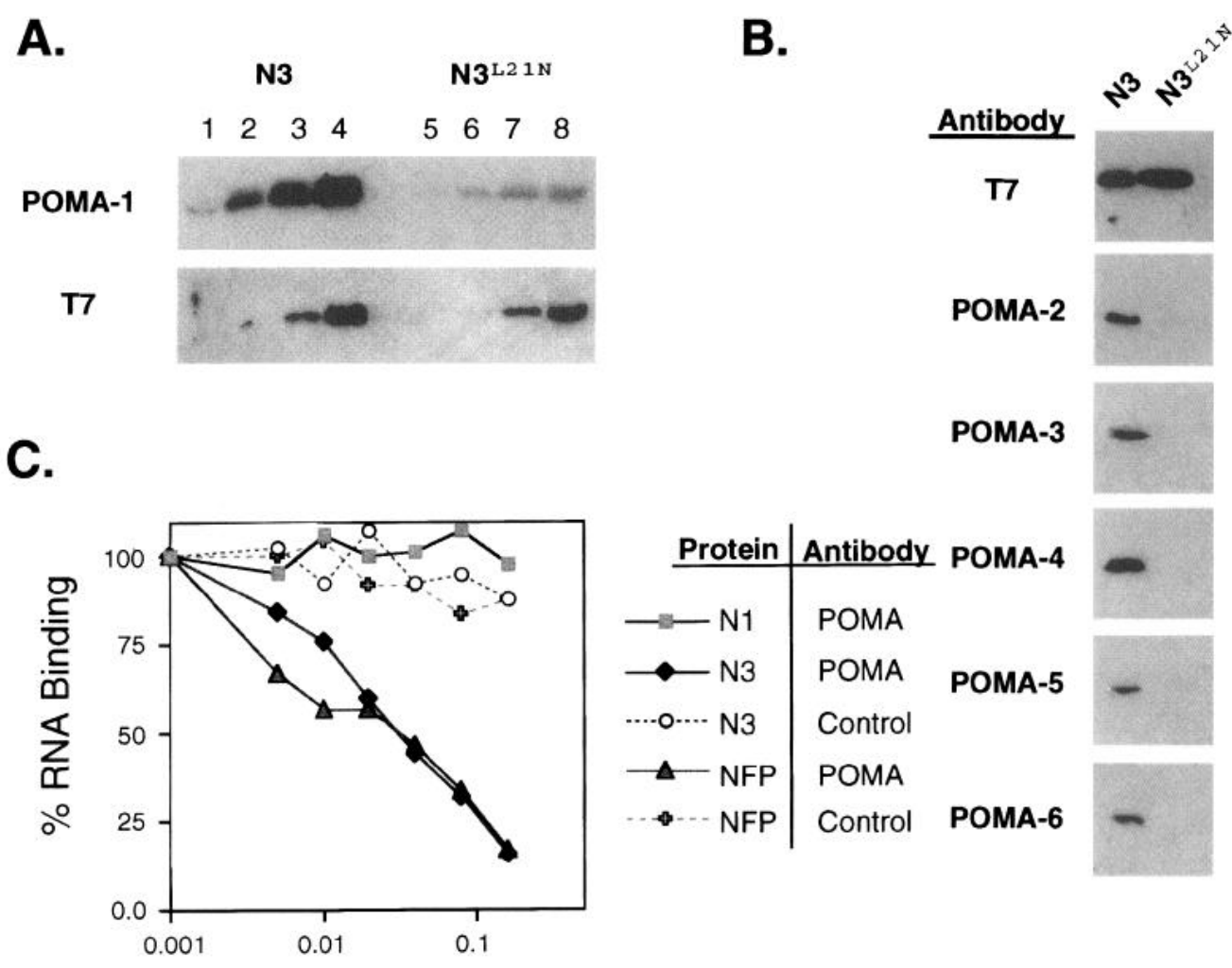

Antibody Dilution 
Alternatively, in the NFP, binding of RNA to the third Nova-1 KH domain may be a necessary prerequisite for binding of RNA to the first and second Nova-1 KH domains; such an effect could be mediated via structural or cooperative changes in Nova-1.

Our results suggest that the POMA antibody has the potential to eliminate RNA-binding function of Nova-1 in vivo and, therefore, the neurological disorder may be caused by loss of Nova-1 activity. Antibody-mediated disruption of protein function would provide a mechanism compatible with the observation that neurological symptoms are reversible in some POMA patients (Posner and Furneaux, 1990; Darnell, 1994). Our understanding of the pathogenesis of the paraneoplastic syndromes, including POMA, conflicts with current understanding of immunity and the nervous system. PND antigens, including Nova-1, are intracellular (the Nova antigen is present in both the cytoplasm and nucleus; Fig. 1). However, presentation of intracellular proteins via major histocompatibility complex (MHC) I or MHC II molecules generally is not thought to occur in neurons (Lampson, 1987; Lampson et al., 1994), complicating the hypothesis that the disorders are T cellmediated. There is a higher specific activity of antibodies in the CSF than in the serum of PND patients (Furneaux et al., 1990), suggesting that $\mathrm{B}$ cclls invade the nervous system. Moreover, although the data are not fully compelling, there is some experimental evidence to suggest that paraneoplastic antibodies accumulate within neurons after injection of $\operatorname{IgG}$ into the CSF in vivo (Graus et al., 1991) or after incubation of IgG with neurons in vitro (Greenlee et al., 1993). These observations suggest that at least some neurons have the ability to internalize pathogenic antibodies, where they may act to inhibit the function of specific target proteins.

\section{REFERENCES}

Abitbol M, Menini C, Delezoide A, Rhyner T, Vekemans M, Mallet J (1993) Nucleus basalis magnocellularis and hippocampus are the major sites of FMR-I expression in the human fetal brain. Nature Genet $4: 147-153$.

Anderson NE, Rosenblum MK, Posner JB (1988) Paraneoplastic cerebellar degeneration: clinical-immunological correlations. Ann Neurol $24.559-567$

Ashley CT, Wilkinson KD, Reines D, Warren SI (1993) FMRI protein: conserved RNP family domains and selective RNA binding. Science 262:56.3-566.

Baker B (1989) Sex in flies: the splice of life. Nature 340:521-524.

Bellen HJ, Kooyer S, D'Evelyn D, Pearlman J (1992) The Drosophila couch potato protein is expressed in nuclei of peripheral neuronal precursors and shows homology to RNA-binding proteins. Genes Dev 6:2125-2136.

Buckanovich R, Posner JB, Darnell RB (1993) Nova, the paraneoplastic $\mathrm{Ri}$ antigen, is homologous to an RNA-binding protein and is specifically cxpressed in the developing motor system. Neuron 11:657-672.

Burd C, Dreyfuss G (1994) Conserved structures and diversity of functions of RNA-binding proteins. Science 265:615-621.

Campos AR, Grossman D, White K (1985) Mutant alleles at the locus elav in Drosophila melon lead to nervous system defects: a developmental-genetic analysis. J Neurogenet 2:197-218.

Chomcynski P, Sacchi N (1987) Single-step method of RNA isolation by acid guanidinium thiocyanate-phenol-chloroform extraction. Anal Biochem 162:156-159.

Dalmau J, Furneaux HM, Gralla R.I, Kris MG, Posner IB (1990) Detection of the anti-Hu antibody in the serum of patients with small cell lung cancer: a quantitative Western blot analysis. Ann Neurol 27:544-552.

Dalmau J, Graus F, Rosenblum MK, Posner JB (1991) Anti Hu associated paraneoplastic encephalomyelitis/sensory neuropathy: a clinical study of 71 patients. Medicine 71:59-72.

Darnell RB (1994) Paraneoplastic syndromes. In: Current diagnosis in neurology (Feldmann E, ed), pp 137-141. Philadelphia: Mosby.

Darnell RB, DeAngelis LM (1993) Regression of small-cell lung carcinoma in patients with paraneoplastic neuronal antibodies. Lancet $341: 21-22$.
DeBoulle K, Verkerk A, Reyniers E, Vits L, Hendrickx J, Van Roy B, Van Den Bos F, de Graaff E, Oostra B, Willems P (1993) A point mutation in the $F M R-1$ gene associated with fragile $\mathrm{X}$ mental retardation. Nature Genet 3:31-35.

Devys D, Lutz Y, Rouyer N, Bellocq J, Mandel J (1993) The FMR-1 protein is cytoplasmic, most abundant in neurons and appears normal in carriers of a fragile X permutation. Nature Genet 1:335-340.

Dizhoor AM, Ray S, Kumar S, Niemi G, Spencer M, Brollcy D. Walsh KA, Philipov PP, Hurley JB, Stryer L (1991) Recoverin: a calcium sensitive activator of retinal rod guanylate cyclase. Science 251:915-918.

Dreyfuss G, Matunis MJ, Piñol-Roma S, Burd CG (1993) hnRNP proteins and the biogenesis of mRNA. Annu Rev Biochem 62:289-321.

Dropcho E, Chen Y, Posner J, Old L (1987) Cloning of a brain protein identified by autoantibodies from a patient with paraneoplastic cerebellar degeneration. Proc Natl Acad Sci USA 84:1-5.

Engebrecht J, Rocder GS (1990) MERI, a yeast gene required for chromosome pairing and genetic recombination, is induced in meiosis. Mo Cell Biol 10:2379-2389.

Engebrecht JA, Voelkel-Meiman K, Roeder GS (1991) Meiosis-specific RNA splicing in yeast. Cell 66:1257-1268.

Fathallah-Shaykh H, Wolf S, Wong E, Posner J, Furneaux H (1991) Cloning of a leucine-zipper protein recognized by the sera of patients with antibody-associated paraneoplastic cerebellar degeneration. Proc Natl Acad Sci USA 88:3451-3454

Furneaux H, Reich L, Posner J (1990) Autoantibody synthesis in the central nervous system of patients with paraneoplastic syndromes. Neurology 40:1085-1091.

Gibson T, Rice P, Thompson J, Heringa J (1993) KH domains within the FMR 1 sequence suggest that fragile $X$ syndrome stems from at defect in RNA metabolism. Trends Biochem Sci 18:331-333.

Good PJ (1995) A conserved family of elar-like genes in vertebrates. Proc Natl Acad Sci USA 92:4557-4561.

Graus F, Illa I, Agusti M, Ribalta T, Cruz-Sanchez F, Juarez C (1991) Effect of intraventricular injection of an anti-Purkinje cell antibody (anti-Yo) in a guinea pig model. J Neurol Sci 106:82-87.

Graus F, Rowe G, Fueyo J, Darnell RB, Dalmau J (1993) The neuronal nuclear antigen recognized by the human anti- $\mathrm{Ri}$ autoantibody is expressed in central but not peripheral nervous system neurons. Neurosci Lett 150:212-214.

Gray-Keller MP, Polans AS, Palczewski K, Detwileı PB (1993) The effect of Recoverin-like calcium-binding proteins on the photoresponse of retinal rods. Neuron 10:523-531.

Greenlee JE, Parks TN, Jaeckle KA (1993) Type IIa ("anti-Hu") antineuronal antibodies produce destruction of rat cerebellar granule neurons in vitro. Neurology 43:2049-2054.

Hanzlik AJ, Osemlak-Hanzlik M, Hauser MA, Kurnit DM (1993) A recombination-based assay demonstrates that the fragile $X$ sequence is transcribed widely during development. Nature Genet 3:44-47.

Hinds HL, Ashley CT, Sutcliffe JS, Nelson DL, Warren ST, Housman DE. Schalling M (1993) Tissue specific expression of $F M R-I$ provides evidence for a functional role in fragile $X$ syndrome. Nature Genet $3: 36-43$.

Hormigo A, Dalmau J, Rosenblum MK, River ME, Posner JB (1994) Immunological and pathological study of anti-Ri-associated encephalopathy. Ann Neurol 36:896-902.

Jean WC, Dalmau J, Ho A. Posner JB (1994) Analysis of the IgG subclass distribution and inflammatory infiltrates in patients with antiHu-associated paraneoplastic encephalomyelitis. Neurology 44:140-147.

Kawamura S, Hisatomi O, Kayada S, Tokunaga F, Kuo CH (1993) Re coverin has S-modulin activity in frog rods. J Biol Chem 268:14579-14582.

Kim Y-J, Baker B (1993) The Drosophila gene rbp9 encodes a protein that is a member of a conserved group of putative RNA-binding proteins that are nervous system-specific in both flies and humans. J Neurosci 13:1045-1056.

King P, Levine T, Fremeau R, Keene J (1994) Mammalian homologs of Drosophila FI.AV localized to a neuronal subset can bind in vitm to the 3 -untranslated region of mRNA encoding the Id transcriptional repressor. J Neurosci 14:1943-1952.

Lampson L (1987) Molccular bases of the immune response to ncural antigens. Trends Neurosci 10:211-216.

Lampson LA, Grabowska A, Whelan JP (1994) Class I and Il MHC expression and its implications for regeneration in the nervous system. Prog Brain Res 103:307-317. 
Levine TD. Gåo F, King PII, Andrews LG, Keene JD (1993) Hel-N1: an autoimmune RNA-binding protein with specificity for $3^{\prime}$ uridylate-rich untranslated regions of growth factor mRNAs. Mol Cell Biol 13:3494-3504.

Luque $F$, Furneaux $H$, Ferziger $R$, Rosenblum $M$, Wray $S$, Schold $S$, Glantz M, Jaeckle K, Biran H, Lesser M, Paulsen W, River M, Posner J (1991) Anti-Ri: an antibody associated with parancoplastic opsoclonus and breast cancer. Ann Neurol 29:241-251.

Mahone M. Saftman EE, Lasko PF (1995) Localized Bicaudal-C RNA encodes a protein containing a $\mathrm{KH}$ domain, the RNA binding motif of FMR I. EMBO J 9:2043-2055.

Matunis MJ. Michael WM. Dreyfuss G (1992) Characterization and primary structure of the poly(C)-binding heterogenous nuclear ribonucleoprotein complex K protein. Mol Cell Biol 12:164-171.

McCarthy JEG, Kollmus H (1995) Cytoplasmic mRNA-protein interactions in cukaryotic gene expression. 'Irends Biol Sci 20:191-197.

Nakamura M, Okano H, Blendy JA, Montell C (1994) Musashi, a neural RNA-binding protein required for Drosophila adult external sensory organ development. Neuron 13:67-81.

Nandabalan K. Roeder GS (1905) Binding of a cell-type-specific RNA splicing factor to its target regulatory sequence. Mol Cell Biol $15: 1953-1960$

Newman LS, McKeever MO, Okano HJ, Darnell RB (1995) $\beta$-NAP, a cerebellar degeneration antigen, is a neuron-specific vesicle coat protein. Cell 82:773-783.

Peterson K. Rosenblum MK, Kotanides H, Posner JB (1992) Paraneoplastic cerebellar degeneration. I. A clinical analysis of 55 anti-Yo antibody-positive patients. Neurology 42:1931-1937.

Pinol-Roma S. Dreyfuss G (1992) Shuttling of pre-mRNA binding proteins between nucleus and cytoplasm. Nature 355:730-732.

Polans AS, Buczylko J, Crabb J, Palczewski K (1991) A photoreceptor calcium binding protein is recognized by autoantibodies obtained from patients with cancer-associated retinopathy. J Cell Biol 112:981-989.

Posner JB, Furneaux HM (1990) Paraneoplastic syndromes. In: Immunologic mecharisms in neurologic and psychiatric disease (Waksman BH. ed), pp 187-219. New York: Raven.

Queva C. Ness SA. Graf T, Vandenbunder B, Stehelin D (1992) Expression patterns of $\mathrm{c}-m y b$ and of $\mathrm{v}-m y b$ induced myeloid-l (mim-l) gene during the development of the chick embryo. Development $114: 125-133$.

Richter K, Good PJ, Dawid IB (1990) A developmentally regulated, nervous system-specific gene in Xenopus encodes a putative RNAbinding protein. New Biol 2:556-565.
Sakai K, Gofuku M, Kitagawa Y, Ogasawara T, Ilirosc G, Yamazaki M, Koh CS, Yanagisawa N, Steinman L (1993) A hippocampal protein associated with paraneoplastic neurologic syndrome and small cell lung carcinoma. Biochem Biophys Res Commun 199:1200-1208.

Sakai K, Mitchell D, Tsukamoto T, Steinman L (1990) Isolation of a complementary DNA clone encoding an autoantigen recognized by an anti-neuronal antibody from a patient with paraneoplastic cercbellar degeneration. Ann Neurol 28:692-698.

Siebel CW, Admon A, Rio DC (1995) Soma-specific expression and cloning of PSI, a negative regulator of P element pre-mRNA splicing. Genes Dev 9:269-283.

Siomi H, Choi M, Siomi M, Nussbaum R, Dreyfuss G (1994) Essential role for $\mathrm{KH}$ domains in $\mathrm{RNA}$ binding: impaired $\mathrm{RNA}$ binding by a mutation in the KH domain of FMR1 that causes fragile $X$ syndrome. Cell 77:33-39

Siomi H, Siomi M, Nussbaum R, Dreyfuss G (1993) The protein product of the fragile $X$ gene, FMR1, has characteristics of an RNA-binding protein. Cell 74:291-298.

Swanson MS, Dreyfuss G (1988) Classification and purification of proteins of heterogenous nuclear ribonucleoprotein particles by RNAbinding specificities. Mol Cell Biol 8:2237-2241.

Szabo A, Dalmau J, Manley G, Rosenfeld M, Wong E, Henson J, Posner JB, Furneaux HM (1991) HuD, a parancoplastic encephalomyelitis antigen contains RNA-binding domains and is homologous to Elav and Sex-lethal. Cell 67:325-333.

Tan E (1991) Autoantibodies in pathology and cell biology. Cell 67:841..842.

Thirkill CE, Tait RC, Tyler NK, Roth AM, Keltner JL (1992) The cancer-associated retinopathy antigen is a Recoverin-ljke protein. Invest Ophthalmol Vis Sci 33:2768-2772.

Valcarcel J, Singh R, Zamore P, Green M (1993) The protein Sex-lethal antagonizes the splicing factor $\mathrm{U} 2 \mathrm{AF}$ to regulate alternative splicing of transformer pre-mRNA. Nature 362:171-175.

Wong G, Muller O, Clark R, Conroy L, Moran M, Polakis P. McCormick F (1992) Moleculas cloning and nucleic acid binding propertien of the GAP-associated tyrosine phosphoprotein p62. Cell 69:551-558.

Yao K-M, Samson M-L, Reeves R, White K (1993) Gene elav of Drosophila melanogaster: a prototype for neuron-specific RNA binding protein gene family that is conserved in flies and humans. J Neurobiol $24: 723-739$. 